\title{
A Qualitative Exploratory Study of the Factors Causing Academic Stress in Undergraduate Students in Pakistan
}

\author{
Muhammad Saeed*1 ${ }^{1}$ Zahid Ullah $^{2} \&$ Iqbal Ahmed $^{3}$ \\ 1.Department of Global \& Social Studies, King Fahd University of Petroleum \& Minerals, Saudi Arabia. \\ 2. Department of Education, Faculty of Social Sciences, University of Malakand, Chakdara, Pakistan.
}

Received: April 18, 2020

Published Online: December 05, 2020

\begin{abstract}
Academic stress is becoming an alarming mental health problem in Pakistan. The study aims to explore the causes of academic stress in the undergraduate students in Khyber Pakhtunkhwa, Pakistan. Qualitative exploratory research design is adopted for this study. Data is elicited through structured-interview guide from 80 students from different study programs at the University of Malakand. Findings of the study show that nearly all (96.25\%) students experienced an academic stress. Further, main causes of academic stress mentioned by students include: the lack of time management (90\%); the semester system and frequent exams (86\%); high study load and lengthy syllabi (80\%); financial constraints (78\%); favouritism and discrimination (72\%); ineffective teacher-student relationship (68\%); conventional and multilingual teaching style (60\%); family and parental expectations $(56 \%)$; and difficulty in adjustment to the university environment (44\%). This study concludes that academic stress can be curbed by revamping on the identified factors, establishment of effective counselling services, and other efficient coping strategies.
\end{abstract}

Keywords: Academic Stress, Undergraduate Students, Qualitative Study, Discourse Analysis, Education in Pakistan.

\section{Introduction}

Academic stress has become part of students' life due to various internal and external expectations (Reddy et al., 2018). Academic stress refers to students' response to educational related demands that exceed their available resources, adaptive and coping capabilities (Alsulami et al., 2018). However, stress response varies among students contingent on their personalities and study programs, and socio-cultural circumstances (Uchil, 2017). Stress related events are happening regularly among students in Pakistan. One example of this is the increased rate of students' suicide over the past few years in Pakistan (Bashir et al., 2019). For example, Shakil (2019) in a retrospective study of 11 newspapers from 2010 to 2017, found 68 cases of students' suicide $(76.5 \%$ suicide rate among male students while $23.5 \%$ among females) in Pakistan. The figures are believed to be many fold higher as such events go unreported due to associated socio-cultural and religious stigma (Shakil, 2019).

Presently, the educational system, its standard and expectations exert enormous pressure on students in Pakistan (Khan et al., 2013). In Pakistani culture, expectations of the family significantly impact students' performance, learning and stress. However, it often does more 
harm than good to students (Reddy et al., 2018). This implies that undergraduate students are vulnerable to different stressors. It needs significant attention as it raises serious mental and public health concerns (Nandamuri \& Gowthami, 2011). This study argues that academic stress if not identified and tackled on time can lead to serious mental health and behavioural complications. Young students, 15 to 22 year of age are often more vulnerable to academic stress as they experience a transition in life (Reddy et al., 2018). This study argues that since youth constitute about $60 \%$ of the population of Pakistan, the progress and prosperity of Pakistan heavily rely on them. Therefore, it is imperative to understand the sources and impact of academic stress among undergraduate students. It would help the development of effective counselling modules and intervention strategies for alleviating students' stress. This study therefore aimed to explore the factors causing academic stress in undergraduate students in Pakistan, the University of Malakand in specific.

\section{Rationale and Significance of the Study}

Much of the recent studies on academic stress in Pakistan have mainly focused on medical students (Jahan et al., 2016; Shakil, 2019; Yousaf et al., 2016; Bashir et al., 2019; Syed et al., 2018). No study has been conducted on the causes of academic stress on undergraduate students in the public sector universities of Pakistan, the University of Malakand in specific. In this regard, this study aims to reduce this gap in the literature by providing original insight of the stressors encountered by undergraduate students at the University of Malakand. Since stress has extensive outcomes on the learning capacity and mental wellbeing of undergraduate students (Elias et al., 2011), essential coping interventions should be introduced to give students a protected domain, feeling of accomplishment and positive energy (Reddy et al., 2018). In this way the results and findings of this study would be of great significance as it will provide a holistic insight to present and future students to better grasp the stressors, and the avoiding/coping avenues for it. This study will be important for teachers, parents, and school administration to understand the phenomenon of academic stress, and to facilitate/establish the initiatives effectively alleviate the stress. Further, the finding of this research will be useful to contemporary researchers, policy makers, and public health officials.

\section{Literature Review}

Academic stress has become a major mental health concern across the world these days. Studies estimate that 10 to 30 percent students suffer from some degree of academic stress during their academic journey (Alsulami et al., 2018). For example, in India a study reported that more than half of the students are affected by depression (51.3\%), anxiety (66.9\%) and stress (53\%) (Iqbal et al., 2015). A study in Canada noted that $30 \%$ of students has psychological morbidities (Adlaf et al., 2001). Similarly, more than 50\% students in the United State (Mosley et al., 1994), 53\% in Australia (Stallman, 2008), 41.9\% in Malaysia (Sidik \& Kaneson, 2003), and $38 \%$ students in Iran faced depression and other mental health problems (Sarokhani et al., 2013). In Turkey, depression, anxiety and stress were recorded as $27.1 \%, 47.1 \%$ and $27 \%$ respectively (Bayram \& Bilgel, 2008). In Pakistan, a research study found that depression, anxiety and stress among undergraduate students were $48.0 \%, 68.54 \%$ and $53.2 \%$, respectively (Syed et al., 2018). Consequently, there is a growing recurrence of stress related events among students such as suicide, drug addiction, quitting of education and other mental abnormalities in Pakistan (Syed et al., 2018).

The literature documents numerous reasons of stress in undergraduate students. For example, 
it relates to financial constraints, old fashioned teaching methodology and rote learning, lack of social activities, and study workload (Pulido-Martos et al., 2011) overcrowded lecture halls, semester grading system, surprises quizzes, deadlines, inadequate resources and facilities, excessive assignments and exams (Nandamuri \& Gowthami, 2011); poor time management (Tresca, 2020), peer competition, lack of effective and objective student-teacher relationships. Furthermore, apprehension of failure; frequent scolding by parents, teachers or peers can cause stress (Shakil, 2019). Low academic grades lead to the feelings of guilt, alienation, hopelessness, worthlessness, and lower the self-esteem and sleep time of students (Misra \& McKean, 2000). The extreme stress could produce serious health complications, a change in behaviour such as quitting academic studies, use of drugs, indulgence in crimes, and in extreme cases drive the students to attempt/commit suicide (Khan \& Chaudary, 2014; Naveed et al., 2017). These mentioned reasons of academic stress (as this study attempts to explore through the subjective experience of students) are also true in the context of Pakistani society and academic settings.

Academic stressors can be classified into six broad categories (Bashir et al., 2019). These are:

a) Academic Related Stressors (ARS): It entails any educational, institutional, instructive or understudy situations that affects students' performance and causes stress (Bashir et al., 2019; Manjula et al., 2012). Some of the ARS identified in the Pakistani context include competitive learning environment, exam anxiety, lengthy content to learn, low grades, difficulty to understand learning content, not clear in choosing majors and courses of study, tough academic schedule, lack of time for revision, and having low attendance (Bashir et al., 2019; Khan \& Chaudary, 2014; Lal, 2014).

b) Interpersonal Related Stressors (InterRS): These relate with relationship among people. These include physical, verbal, mental and emotional mistreat and troubles caused by instructors, staff, family members, peers, and associates. For example, conflict with peers and family members, too many assignments given by the instructors, unwilling to go to university, crowded classrooms, bullying, and interruption by others (Bashir et al., 2019).

c) Intrapersonal Related Stressors (IntraRS): These refer to relationships of a person with him/herself, for instance self-conflict, feeling of inadequacy, low self-esteem and confidence, high self-desire to be better academically (Al-Qahtani \& Alsubaie, 2020; Yusoff, 2011).

d) Group Social related stressors (GSRS): These are identified as the type of gathering events and communications, group and social network connections that lead to stress (Zenkour \& Alghanmi, 2019). For example, participation in discussion, presentation with groups and the desire to do well, time spending with family and working interruption by others (Abouserie, 1994; Bashir et al., 2019; Yusoff, 2011).

e) Learning and Teaching Related Stressors (LTRS): These include situations pertaining to teaching or learning that cause stress to students. For example, the teaching and learning methods, frustration with the quality of education, ineffective feedback systems and supervision, lack of recognition to work done, and obscurity of what is expected from the students (Bashir et al., 2019; Yusoff, 2011).

f) Teacher Related Stressors (TRS): These are identified as competency and personality of the instructors such as discontent with instructors' supervision abilities, aptitudes, delay or not providing study materials, and assigning of improper and dull tasks to students; which the students find boring (Bashir et al., 2019). This study argues that these mentioned stressors are not mutually exclusive but inclusive and intersect with students' stress in Pakistan. 
Lazarus \& Folkman's (1984) opine that stress has two aspects that is stressors produced by the environment and the coping strategies available and adopted by a person. They argue that stress is not a straight reaction to a stressor however it is rather one's agility, capability, and resources to deal, cope, mediate the stress response, and are amenable to change, and therefore making stress to be controllable. This implies that when faced with a stressor, the person first reviews his/her potential and resources to deal with it; lacking of which leads to stress. Drawing on Lazarus and Folkman's transitional model of stressors and coping methods, we in this study argue that the existing academic, social, economic, and cultural setting of Pakistan exert enormous pressure on students. These stressors are often beyond the control of the students, and thus cause them stress. Further, the absence of effective coping strategies and interventions in academia and society perpetuate students' distress.

\section{Methodology of the Study}

Qualitative explorative study design was used for this study as it provides a vigorous mode of understanding the complex phenomenon (Creswell, 2007). This study was conducted in the University of Malakand because: it contains diverse academic departments with a heterogeneous students' population; it was convenient and easily accessible to the researchers; and dearth of research study on academic related stress in this university and region. Data was collected from 80 male students, 8 ( 2 students from each year of the four years semester system) from 10 different departments (see it as Appendix: 2). Students were accessed/recruited through purposive sampling and snowballing technique. This approach enables the researcher to get access to multiple data sources to explore the context in a holistic and diverse way (Creswell, 2007).

A semi-structured interview guide (see Appendix: 1) has been used for the data elicitation. The semi-interview guide consisted of open-ended questions which enabled the participants to provide details about their experiences of academic stress and stressors. Before the interviewing, verbal consent were sought from the study participants about the recording of interview. Further, full liberty and confidentiality of the participants were insured such as using pseudo names instead of their original names, and that they had the freedom to withdraw their views during or after the interview. After the completion of interviews, the audio recoded data was transcribed into textual format. Different themes emerged during the course of repeated readings of the transcribed scripts which were categorized into main themes (first order category) and sub themes (second order category). Similarly, the use of thematic discourse analysis approach helped in the identification of the causes of academic stress from the transcribed data. This method is useful to infer meaning and actions within a sociocultural context (Crowe, 2005).

\section{Study Findings and Discussion}

The following sections threw a light on the identified factors of academic stress, its analysis and discussion.

\subsection{Lake of Time Management}

We noticed that nearly all the students $(90 \%)$ had no or poor time management skills, causing them a great deal of distress and anxiety. For example, Zeeshan Khan $-4^{\text {th }}$ semester Sociology department, said: 
"I do not have any proper schedule and plan for my study...the delaying habit and lack of planning the workload files up... at the end difficult to cover all the contents for the exams...sometimes I suffer from loose motion due to stress."

Issue of procrastination and lack of proper study plan was mentioned by many other students too. Besides, we found that time wastage due to social media addiction has become an alarming issue, and a potential source of stress for students. For example, Ismail Jan $-6^{\text {th }}$ semester Education department, said:

“...I always use social media, Facebook in specific...it sucks my time, and I hardly manage time for studies and homework... during the exams I am under enormous pressure and worry that how I will cover all the materials in short time."

Students said that they spend, on average, 7 to 10 hours daily on social media application. Lack of self-discipline was the main reason of time wastage on social media, mentioned by some students. Since mobile has become an integral part of their lives so avoiding it was hard for them. Similarly, availability of free Wi-Fi service at the university and hostels as well as cheap internet packages by telecom companies increase social media addiction among students. Time management behaviours are related to important outcome variables, including stress and performance (Burge, 2009; Misra \& McKean, 2000). Research shows that effective time management strategy can reduce burnout and distress (Tresca, 2020), and enhances academic outcomes (Campbell \& Svenson, 1992). Educationists view that strategizing the study with effective time management plan such as task scheduling, prioritization of tasks, and frequent measurement of the outcomes are keys to productive learning and upskilling (Misra \& McKean, 2000). However, on the contrary as mentioned by our study respondents, students who ignore these techniques of time management confronted with stressful conditions.

\subsection{The Semester System and Frequent Exams}

Approximately $86 \%$ students mentioned that semester system causes them distress. Many expressed that they had to take and do preparation for five or six subjects and was thus very hard for them to cover all the contents of different subjects in a short period. For example, Gulab Sher Khan - 5th semester Management Studies department, said:

"... I have to cover all the subjects and prepare myself for the exams in a short time... it is very hard to understand all the contents of various subjects."

Since the semester system includes frequent exams, presentations, assignments and quizzes, adjustment to it was hard for many students, and thus caused them a great deal of stress. Schools and colleges adhere to the annual (pass/fail) system where students get plenty of time for preparation. Similarly, annual system offers $50 \%$ option in the selection of questions in the exam papers. In this sense, compatibility with semester system was difficult for junior students.

Some respondents pointed out that the short time between mid-term and final exams put them in great strain. For example, Shahid Aziz-7th semester economics department, said:

“... After the mid-term exam, I have to take regular classes, complete my assignment, and prepare myself for the final term exam... because of this 
routine, I spare no time for social and sports activities, and definitely in stress... difficult for me to manage things."

Continuous exams in the semester system were causing strain for majority of the students we interviewed. Some stated that they have exams on daily basis, and therefore very challenging to do well preparation for different courses in short period. Some mentioned that they become stressful when hear the announcement for the exam. For example, Khan Alam-3rd semester Computer Science department, said:

"... I become nervous and in stress when the department displays the schedule of exams... you know achieving good GPA in some subjects require tough study and conceptual clarity, which of course require enough time."

In the light of the aforementioned accounts of students, this study concludes that the semester system exerts enormous pressure on students. They had to do multiple academic activities such as prepare assignments, presentations, class work and continuous exams. The feeling of accomplishment and apprehension of achieving low grades lead to distress in the semester system. Abouserie, (1994) found that students experiencing academic stress at predictable times each semester with the greatest sources of academic stress resulting from taking and studying for exams, grade competition, and the large amount of content to master in a small amount of time. Studies show that students assessed under grade-tired assessment system were more likely to experience high level of stress, emotional abnormality, burnout as well as considering the option of quitting studies (Reed et al., 2011); while the annual assessment system resulted in greater mental well-being, greater group cohesion, and more satisfaction with the quality of education and personal lives (Spring et al., 2011).

\subsection{High Study Load and Lengthy Syllabi}

Nearly $80 \%$ students mentioned that high study load and lengthy course contents were traumatic and exhaustive for them. For example, Sher Akbar $-6^{\text {th }}$ semester Pharmacy department, said:

“... Teachers try to cover more course contents in classes and burdened us with home assignments... they think we are machines... it is possible to do massive class work and assignments for different courses with tight deadlines."

Echoing to this, a student, Bacha Rahim — 4th semester Computer Science department, added:

"... After the classes I am totally lost and confused that from where and from what subject I should begin... believe me I take antidepressants and have sleeping problem because of the study load...I cannot spare time for sports and other social activities."

Since the students have to take five or six subjects (15 to 18 credit hours) in each semester, giving proper time to each subject was hard for them. Consequently, students have to do selective preparation and ignore the course contents, which are not important from exam point of view, mentioned by some students. However, selective study for exam preparation involves risks as sometimes the ignored course materials could come in the exam, can impact their grades, and cause them a great deal of distress and remorse. Campbell \& Svenson, (1992) found 
that university students are stressed because they are required to develop effective study techniques and habits to cope with the volume of material assigned to them. Britz and Pappas (2010) in a study documented that major causes of stress in students were because of high academic workload and taking more subjects with excessive credit hours in a term. Radcliff and Lester (2003) noted that the most stressful situations for students were the excessive class workload, high credit hours and lengthy syllabi. Our study confirms that high course workload was one of the factors of academic stress among undergraduate university students at the University of Malakand.

\subsection{Financial Constraints}

Nearly all the students at the University of Malakand belong to the Malakand division comprising of 7 districts, a poor and underdeveloped region of Pakistan. Majority of the interviewees (75\%) had poor family background, and had studied at the government schools and colleges with no or minimal tuition fee. On the contrary, university education is quite expensive and difficult to afford for a poor family. For example, a student at the University of Malakand has to pay nearly $\$ 500$ yearly in tuition fee. However, with hostel charges it may reach up to $\$ 1000$ per year. Pashtuns ${ }^{1}$ usually have large family size where father alone sustains the family. Thus, it is difficult for a lower-middle class family to afford the university education of 4 to 5 children. Consequently, in such conditions, often girls are deprived from education as preference is given to male children, elder in specific, due to social, cultural, and economic reasons (Saeed, 2012). It was in this sense that a major proportion of the interviewees (78\%) mentioned difficulties in the payment of tuition fee, hostel charges, food expenses, and stationary buying, causing them a great deal of pressure and stress. For example, Mobarak Jan $-6^{\text {th }}$ semester Chemistry department, said:

“... I belong to a lower-class family and hardly manage to pay the tuition fee...I cannot afford many things such as new books, printing of materials, internet etc... I always worry that whether I will complete my studies or not. I am always drowned in these kinds of thoughts, making me depress."

Another respondent, Jawad Mohammad $-4^{\text {th }}$ semester Biotechnology department, shared similar views as well. He told:

"...after getting admission in the university I was extremely worried that how my family would bear the university expenses...though there are different schemes for the academic support of poor students but you know its process and approval takes a long while, requires strong reference, and involves hectic bureaucratic procedure."

Usually there are various governmental and non-governmental financial support schemes available for the monetary support of poor students in Pakistan. However, these schemes entail different dilemmas such as tough deadlines, proof of low income of the family, lengthy process of scrutiny and selection, and often biased attitudes of the university management. Furthermore, the universities do not allow the payment of fee in instalments or any delay in payments for the poor and needy students. Resultantly, the families of poor students have to pay the tuition fee either had to take a loan, mortgage, or sell the family assets such as shop, land, and livestock. This certainly cause extreme agony not only to the family but also to students of poor families. 
Since, most of the students at the University belonged to lower-class family, they were in constant agony, living in stressful conditions, and worried that weather they will complete their graduation or not. Heckman et al. (2014) in their study found that two of the most important financial stressors were not having enough money to participate in the same activities as peers and expecting to have higher amounts of student loan debt at graduation. Similarly, a study by Archuleta et al. (2013) found that students belonging to poor family mostly become victim of psychological problems such as depression, loneliness, and unbalanced emotions. This, as this study found, is very much true in the context of the University of Malakand.

\subsection{Favouritism and Discrimination}

Significant number of students' participants (72\%) mentioned that they are depressed due to favouritism and discrimination by teachers, administration, staff, and peers at the university. Specifically, indifferent, and arrogant attitudes on the part of teachers were more hurting and traumatic, mentioned by few students. Some students mentioned that teachers favour students by giving them high grades, recommend them for scholarships, appreciate and benefit them. For example, Mohammad Kaleem—5th semester Sociology department, said:

"I work hard and attempt all the papers very well but my grades are always lower than some students because they are favoured by our certain teachers ... teachers give them high marks, franked with them, and appreciate them all the time ... These attitudes of the teachers make us feel inferior and disadvantageous when undeserving students, due to their undue favour, are ahead of me ... This makes me angry, uncomfortable and disturbing."

Reiterating to this, another respondent, Sajid Anwar $-7^{\text {th }}$ semester English department, mentioned about the gender biased attitudes on the part of teachers. He said:

"Some teachers are more attentive towards female students and snub male students in the classroom... we cannot complain because you know...often we feel low, hurtled and depressed when avoided by our own teachers."

Similar views relating to discrimination (in terms of gender) were shared by some other respondents as well. Studies note that undue favour on the part of teachers creates feeling of stress and low self-esteem among students. Discrimination among students could impact the academic performance of the deprived students (Spenc et al., 2016). Indifferent attitude and treatment can negatively influence the social growth of neglected students (Cheng \& Mallinckrodt, 2015). Some studies have found that students who receive discriminatory treatment from teachers become reactionary and develop strong belief in taking revenge and become hardliners in their daily life. Such students develop a negative image of everybody in the society that promotes doubts instead of trust and honesty. Hence, such social discrimination creates an environment of mistrust and poor social relations characterized by dishonesty and contempt (Busse et al., 2017). On the contrary, studies show that students receiving equal, and fair treatment from teachers and guiders become socially and morally sound personalities and show great strength in face of challenges and problems (Abrami et al., 1982). Evidently, this study argues that the absence of students' unions, lack of assessment/evaluation of teachers by students and non-representation of students in the decision-making bodies in the universities make students vulnerable to alienation, oppression, discrimination, and abuse, and cause them a great deal of distress. 


\subsection{Ineffective Teacher Student Relationship}

Students spend almost six hours each day at the university for four to five years. This means that university environment, teachers in specific, have immense influence on them. It can be argued that quality of the teacher significantly impacts the personality building, skills, and learning outcomes of the students. We agree that fostering of stress-free learning climate is embedded in a positive teacher-student relationship (Boynton \& Boynton, 2005). However, the findings of this study show the prevalence of ineffective teacher-student relationship. For example, a high number of students (68\%) reported the absence of effective relationship between teachers and teachers at the University of Malakand. Students mentioned that teachers distance themselves from students, snub students, and treat them in coercive manner. For example, a junior student, Asghar Ali-2nd semester Mathematics department, said:

"In my experience some teachers are very strict and students are not in ease with them...students feel frightened to express their views in the class of such teachers...even students do not ask questions when do not understand the topic as they think that the teacher would mind if they asked the question in class."

Another student, Sareer Ahmed $-4^{\text {th }}$ semester Chemistry department, shard similar views as:

"I am facing problems in my subjects but do not share it with some teachers...I worry that instead of helping they would harm me...our seniors have told us their bad experiences about how badly their teachers had treated them...I personally feel frightened and threatened when get close to teachers...I am about to graduate in a year but still have a gap with my teachers. When I enter the office of some teachers, I feel extremely nervous and frightened."

Similar views were shared by many other students as well. It is a predicament of the higher education in Pakistan that teachers in universities, after the recruitment, are not provided with relevant and needful training in pedagogies, students' engaging strategies, curriculum development strategies, assessment strategies, and treatment with students. Consequently, as this study found, students feel frightened, stressed, and hesitant to communicate and share academic and personal problems with their teachers. Recent research documents a significant impact of the student-teacher relationship on academic outcomes. For example, positive or effective student-teacher relationship has been correlated with academic competencies, problem-solving skills, emotional regulation, interpersonal competencies of students with peers, classroom engagement, academic achievements, and motivation in the learning related processes (Boynton \& Boynton, 2005). Students who feel their teacher is not supportive towards them have less interest in learning and are less engaged in the classroom (RimmKaufman \& Sandilos, 2011). Contrary, teachers when are not friendly, students feel uneasy and are frightened. Students may face some unfamiliar situations like nervousness, worry, frustration, abasement, depression, and teachers can really be helpful in resolving and addressing these issues when shared by students in an open manner (Chen et al., 2006).

\subsection{Conventional and Multilingual Teaching Methodology}

Almost $60 \%$ of the interviewees conceived the teaching methodology at the university as conventional, not engaging, ineffective, and uncreative. Some respondents mentioned that teachers do not inspire their interest in the class. Other asserted that teachers often explain 
course contents in a haphazard manner, further confuse them. Some mentioned that $\mathrm{PhD}$ teachers teach at a highly advanced level. For example, Husnain Khan-3rd semester Biotechnology department, said:

"I do not pick any point from the lectures because some of our teachers are PhDs and teach us course contents at high advanced level...Clearly! They want to show off themselves and their intellect... I come out of the class confused have no idea of what the teacher talked about."

Another student, Sheeda Mohammad $-5^{\text {th }}$ semester Pharmacy department, told:

"I understand some bits of the lecture...but some topics needs to be taught in a different way and methodology...I mean in an interesting way like blending it with modern technology...our teachers use the same boring way of teaching... sometimes we can know that the teacher is killing time and dodging us...some lectures are so boring that students feel sleepy in the class.

Besides, students mentioned that several teachers do not follow the syllabus, teach selected topic and chapters, and finish the syllabus in just four to five weeks. This, they said, put enormous pressure on students during the exams as they struggle to prepare (memorize) all the course contents for different subjects. However, we noticed that students of first to second year had more troubles of understanding the course contents than senior level students. This is because majority of the students had their school and college education from government institutes with Urdu as medium of instruction. Therefore, they had problems to grasp and adopt the English medium of teaching at the university. In this regard, as a solution, an engaging and students' focused learning teaching methodology can enhance the interest and participation of students in classroom activities. However, teachers, as mentioned above, either not equipped, supported, and encouraged to use it. Similarly, when PhD teachers teach at advanced level to junior students, grasping it would be certainly hard for mediocre students. Consequently, students would tent to memorization of content without understanding and retention. This study argues that teachers should prepare each lesson and deliver it in way which is interesting, engaging, and satisfy the needs and intellectual level of the students. This would help mitigate the stress level of students. Innovative and smart teaching methodologies are useful not only in engaging students but also in improving their skills pertaining to critical thinking, presentation, understandability, and academic productivity (Mynbayeva et al., 2017).

Besides, many students also talked about multilingual style of teaching at the University, a source of distress for them. For example, they mentioned that though the course and medium of instruction is English but teachers explain concepts in Pashto or Urdu. It was in this context that some students sarcastically said that if teachers could not teach in English how they expect students to express and write things in perfect English. Consequently, students said that they are nervous giving presentation in English language or attempting the exams in English. Some mentioned that they had to spend more time in learning the English language and vocabulary than understanding the course contents. A recent study at the Women University Swabi Pakistan documented significant relation between language acquisition and academic stress (Rahman et al., 2020). Likewise, research shows that students studying in a foreign language face more academic stress and anxiety, have lower critical thinking and expression abilities compared to students studying in native language (Khawaja et al., 2017; Hashemi, 2011). As per our finding this is very much true in the context of the University of Malakand. 


\subsection{Family/Parental Expectations}

Undoubtedly, parents' role in the development and advancement of children is vital. Specifically, in the context of Pakistan, parental desires have extensive impact on the children's accomplishments. Non-performance up to their expectations can generate stress and feeling of low worth, and non-accomplishment in children. This is very much true in the context of the present study. For example, majority of the students (56\%) mentioned that their family and parents' expectations exert enormous pressure on them. For example, Muhammad Zaman $-7^{\text {th }}$ semester Economics department, said:

"I am always worried and in stress because I am the only person in my family getting university education...My parents have invested in me and I had to reciprocate it by becoming successful in life and could change the conditions of my family, sustain the family, and support the siblings in their studies. It gives me enormous stress that how would I accomplish the dreams of my parents and perform up to their dreams."

Another respondent, Said Lal Jan $-8^{\text {th }}$ semester Computer Science department, said:

"Whenever my relatives visit our home, my parents always talk about my education that our son will also get similar job and position got by Mr. XXX... when I hear these words, I become very energized... however it also makes me worry that whether I will secure a good job in future or not."

From these views, it can be inferred that people of Malakand division acknowledge the value of education. People now know that education can bring economic prosperity to the family by opening new avenues of revenue generation, and enhances the influence, status, and power of the family. In fact, some jobs, achieved through education, are considered prestigious and powerful such as medical doctors, engineers, civil services, bureaucracy, and military officer. Often students and their families idealize these positions in Pakistan. However, securing these prestigious jobs require sweat, hard work and support, both financial and moral, the lacking of it can put students in distress and anxiety. Sometimes parents narrow down the academic choices of the children or force their children to get admission in specific academic programs. To meet societal standards, parents often neglect the natural inclinations of their children and thus squeeze their lives by narrowing their choices and eliminating joy from their children's lives. It often does more damage than good to children as constant parental hogging cause mental agony and shatter their confidence. This is very much true as per the findings of our study. Research documents that most students enrolled at universities have high expectations, which place more demands and stress on them (Tan \& Yates, 2011). Further, another study notes that family and teacher expectations contributed the most in causing high stress and anxiety level among the students (Archuleta et al., 2013).

The worth of students in Pakistani society is tied to academic performance. Further, since the future career prospects of students in Pakistan are influenced by their academic results, therefore a relentless pursuit of excellence in examinations becomes imperative for parents and teachers. The concept of parental vigilance and expectations from children also exists in other society of Asia as well. For example, Tan and Yates (2011) in the context of Singapore noted that cultural emphasis on satisfying parental expectations and the fear of losing of pace put enormous stress on students. They documented that Asian students, Chines in specific, in 
Singapore pressurize themselves to excel academically and work hard to fulfil family obligations alongside the academic expectations and of others such as parents and teachers. The students performing below expectations found it harder to live up to their obligations of satisfying their parental desires which caused them higher levels of academic stress.

\subsection{Adjustment to the University Environment}

The academic and social environment at university is completely different from the school and college environment in terms of freedom, gender structure of classes and nature of exams. Adjustment to the new and changed environment of the university is not easy for many students. It is in this context that a considerable number (44\%) of students mentioned that, at the beginning (first year), they faced troubles in adjustment to the university environment. Many mentioned that they would feel nervous and frightened as well as enthusiastic at the same time. For example, Muddasar Iqbal—8th semester Education department, said:

"I thought that university will be just like college but it was completely different...its environment is quite contrast and different... I went through a lot of troubles at the start...I would feel nervous, shy and frightened...It took me a long while to adopt to the university culture and environment."

Study findings show that transition of students from school environment to university environment could cause a psychological, academic, and social shock to them (Hussien \& Hussien, 2006). At university level, students face new methods of teaching, new academic requirements, new type of relations between students and faculties and even new relations among students themselves, therefore adjustment to it is not easy and often leads to stressful conditions (Hussien \& Hussien, 2006). Likewise another study noted that maximum students are stressed because the university students live in an environment quite different from nonstudent peers, the pressure to earn good grades and earn a degree is very high among university students (Shields, 2001).

The most depressing and stressful situation faced by the new comers is the prevalence of a harmful tradition called "fooling games" at the university. Some students mentioned that they were teased, harassed, abused, and mentally tortured by their senior students in classes and hostels through the fooling games and acts. Few mentioned that they did not understand the game of fooling at the beginning but later enjoyed it and helped them to develop rapport with the senior students. Studies have shown that changing social environment create new challenges for students. For example, when they leave home and enter the educational institutions, they face new culture, new challenges, and new people. Normally they get confused and try to adjust. However, adjustment is a time taking phenomenon therefore many students show mal-adjustment due to different factors like shyness, low self-esteem, and socioeconomic background (Qamar et al., 2015).

We noticed that many students had troubles to adjust to hostel life. A study discovered that students developed high depression when admitted in hostel and felt better when they were sent home (Misra \& McKean, 2000). Some students are home sick and when out of home feel uncomfortable and less secured. Further, since students have to do everything on their own at hostels such as food arrangement and cleaning of clothes, they feel overburdened and develop stress and depression. Studies have further elaborated that social displacement is a strong predictor of stress and tension. Home displacement is a factor that creates stress among students 
and they feel more disturbed when out of home (Teh et al., 2015). Students are stressed because they have to adjust to being away from home for the first time, maintain a high level of academic achievement, and adjust to a new social environment (Davis et al., 2006).

\section{Conclusion}

This study aimed to explore the factors causing academic stress among undergraduate students at the University of Malakand. This study implied qualitative exploratory research design for data elicitation, data analysis, and drawing inferences. This study found that academic stress is caused by multiple inclusive factors. Specifically, this study identified that students were stressed because they had no proper management of time skills. Similarly, wastage of time though procrastination and social media addiction were causing them a great deal of distress. The semester system featured by frequent exams, lengthy syllabi, and high work load had immense pressure on students and caused them. Many students were stressed because of their low socio-economic status and difficulties for their family in paying of tuition fee and hostel charges, purchasing reading materials like books and internet, and printing of reading materials. Similarly, students felt stressed due to favouritism and discrimination during classes, exams, and evaluations. Due to ineffective student-teacher relationship, students felt hesitant to share their experiences and issues with teachers, and therefore depressed. Conventional and multilingual teaching style were troubling students as they had to spend more time in the learning of English language than understanding and retaining the course concepts. The prevailing conventional teaching featured were though boring, less engaging, and not inspiring, caused stress to students. Further, students felt under stress to perform up to the family and parental expectations and fulfil their desires. Difficulty in adoptability to the university environment, and academic culture was hard for some students, and generated stress for them. Overall, besides the individual specific factors such as lack of time management, reasons of academic stress among the undergraduate students at the University of Malakand; academic stress is also the result of an ineffective educational system and academic settings, discriminative and abusive treatment, conventional teaching style, economic constraints, and parental pressure for academic excellence.

\subsection{Recommendations}

Based on the conclusions, the following recommendations are forwarded to the relevant fora deal and cope with the problem of academic stress among university students: a) there is a need to create a friendly and supportive environment in the university level, department level and classroom level. This will help students feel at ease, owned, engaged, and encouraged. b) Teachers need to provide equal treatment to students rather than showing discriminatory attitudes. This will motivate students to develop positive manners, and enthusiasm for learning and progress. c) Time management skills and practices need to be initiated, improved, and implemented in students. d) The semester system needs to be revisited and such measures de adopted which rationalizes the time for exam conduction so that students may find enough time for preparation. e). Parents need to be rational in their approach towards their children. They should not be imposing, and be accommodative in terms of academic performance of the children. f) Teachers need to adopt modern, robust, and engaging teaching and learning methods. g) Besides, there is a need of fostering and adopting of effective coping strategies such as reading regular pray, upholding to Islamic values for self-disciplining, participation in sports and other social/community activities, rationalizing distress as in ones' fate and from God's side and therefore enduring it, avoiding it, and using antidepressants. h) Based on the 
analysis, it is suggested that the university teachers, management, and parents forge strong mutual relations to overcome the academic stress among students.

\subsection{Future Directions}

The findings of this may be validated in other provinces of Pakistan as there a deep variation in Pakistan in terms of culture, gender, language, and geographical locations, because these factors could also affect the results of the study. Further studies need to adopt more sample and robust methods to valuate this important issue in the context of Pakistani education.

\section{References}

Abouserie, R. (1994). Sources and Levels of Stress in Relation to Locus of Control and Selfesteem in University Students. Educational Psychology, 14(3), 323-330. https://doi.org/10.1080/0144341940140306

Abrami, P. C., Perry, R. P., \& Leventhal, L. (1982). The Relationship between Student Personality Characteristics, Teacher Ratings, and Student Achievement. Journal of Education and Psychology, 74(1), 111-125. https://doi.org/10.1037/0022$\underline{0663.74 .1 .111}$

Adlaf, E., Gliksman, L., Demers, A., \& Newton-Taylor, B. (2001). The Prevalence of Elevated Psychological Distress among Canadian Undergraduates: Findings from the 1998 Canadian Campus Survey. Journal of American College Health, 50(24), 67-72. https://doi.org/10.1080/07448480109596009

Al-Qahtani, M., \& Alsubaie, A. (2020). Investigating Stress and Sources of Stress Among Female Health Profession Students in a Saudi University. Journal of Multidisciplinary Healthcare, 13, 477-484. https://www.ncbi.nlm.nih.gov/pmc/articles/PMC7250295/

Alsulami, S., Al Omar, Z., Binnwejim, M., Alhamdan, F., Aldrees, A., Al-bawardi, A., . . . Alhabeeb, M. (2018). Perception of Academic Stress among Health Science Preparatory Program Students in two Saudi Universities. Advances in Medical Education and Pracitce, 9, 159-164. https://doi.org/10.2147/AMEP.S143151

Archuleta, K. L., Dale, A., \& Spann, S. M. (2013). College Students and Financial Distress: Exploring Debt, Financial Satisfaction, and Financial Anxiety. Financial Counseling and Planning, 24(2), 50-62. https://files.eric.ed.gov/fulltext/EJ1043230.pdf

Bashir, A., Amir, A., \& Bajwa, K. M. (2019). An Investigation of Stressors among University Students: A qualitative Approach. UCP Management Review, 3(1), 5-24. https://doi.org/10.24312/ucpmr020225

Bayram, N., \& Bilgel, N. (2008). The prevalence and socio-demographic correlations of depression, anxiety and stress among a group of university students. Soc Psychiatry Psychiatr Epidemiol, 43(8), 667-672. https://doi.org/10.1007/s00127-008-0345-x.

Boynton, M., \& Boynton, C. (2005). Educator's guide to preventing and solving discipline problems. Alexandria. USA: Association for Supervision and Curiculum Development. http://www.ascd.org/publications/books/105124.aspx

Britz, J., \& Pappas, E. (2010). Sources and Outlets of Stress among University Students: Correlations between Stress and Unhealthy Habits. URJHS-Undergraduate Research Journal for the Human Science, 9(1). https://www.kon.org/urc/v9/britz.html

Burge, J. (2009). Coping Frequency, Coping Effectiveness, Personality Factors in University Students. Unpublished honors thesis, University of Canberra, Australia. 
Busse, D., Yim, I. S., \& Campos, B. (2017). Social Context Matters: Ethnicity, Discrimination and Stress Reactivity. Psychoneuroendocrinology, 83, 187-193. https://doi.org/10.1016/j.psyneuen.2017.05.025

Campbell, R. L., \& Svenson, L. W. (1992). Perceived Level of Stress among University Undergraduate Students in Edmonton, Canada. Perceptual and Motor Skills, 75, 552554. https://doi.org/10.2466/pms.1992.75.2.552

Chen, F., Lin, Y., \& Tu, C. (2006). A Study of the Emotional Intelligence and Life Adjustment of Senior High School Students. World Transactions on Engineering and Technology Education, $5(3)$, 473-476. http://www.wiete.com.au/journals/WTE\&TE/Pages/Vol.5,\%20No.3\%20\%282006\% 29/22_Chen37.pdf

Cheng, H.-L., \& Mallinckrodt, B. (2015). Racial/Ethnic Discrimination, Posttraumatic Stress Symptoms, and Alcohol Problems in a Longitudinal Study of Hispanic/Latino College Students. Journal of Counseling Psychology, 62(1), 38-49. https://doi.org/10.1037/cou0000052

Cresswell, J. W. (2007). Qualitative inquiry \& research design: Choosing among five approaches $\left(2^{\text {nd }}\right.$ ed.). SAGE. https://psycnet.apa.org/record/2006-13099-000

Crowe, M. (2005). Discourse Analysis: Towards and Understanding of its Place in Nursing. Journal of Advanced Nursing, 51(1), 55-63. https://doi.org/10.1111/j.13652648.2005.03461.x

Davis, K., Winsler, A., \& Middleton, M. (2006). Students' Perceptions of Rewards for Academic Performance by Parents and Teachers: Relations with Achievement and Motivation in College. Journal of Genetic Psychology, 167(2), 211-220. https://doi.org/10.3200/GNTP.167.2.211-220

Elias, H., Ping, W. S., \& Abdullah, M. C. (2011). Stress and Academic Achievement among Undergraduate Students in Universiti Putra Malaysia. Procedia - Social and Behavioral Sciences, 29, 646-655. https://doi.org/10.1016/j.sbspro.2011.11.288

Hashemi, M. (2011). Language Stressa and Anxiety among the English Language Learners. Social and Behavioral Sciences, 30, 1811-1816. https://core.ac.uk/download/pdf/82059045.pdf

Heckman, S., Lim, H., \& Montalto, C. (2014). Factors Related to Financial Stress among College Students. Journal of Financial Therapy, 5(1), 19-39. doi: https://doi.org/10.4148/1944-9771.1063

Hussien, T., \& Hussien, S. (2006). Strategies for Coping Educational and Psychological Stress. Dar Alfiker, Amman. https://doi.org/10.12691/ajphr-3-6-3

Iqbal, S., Gupta, S., \& Venkatarao, E. (2015). Stress, Anxiety \& Depression among Medical Undergraduate Students \& their Sociodemographic Correlates. Indian Journal of Medical Research, 141(3), 354-357. https://doi.org/10.4103/0971-5916.156571

Jahan, F., Siddiqui, M. A., Mitwally, M., Zubidi, A., Jasim, N. S., Zubidi, A., \& Jasim, H. S. (2016). Perception of Stress, Anxiety, Depression and Coping Strategies among Medical Students at Oman medical college. Middle East Journal of Family Medicine, 99(3719), 1-8. https://doi.org/10.5742/MEWFM.2016.92856

Kadapatti, M. G., \& Vijayalakshmi, A. H. M. (2012). Stressors of Academic Stress: A study on Pre-university Students. Indian Journal of Scientific Research., 3(1), 171-175. https://www.indianjournals.com/ijor.aspx?target=ijor:ijsr1\&volume=3\&issue=1\&ar $\underline{\text { ticle }=030}$ 
Khan, A. M., \& Chaudary, A. M. (2014). Impact of Stress among Students of a Public Sector University. Journal of Research and Reflections in Education, 8(1), 48-54. https://tehqeeqat.org/downloadpdf/2514

Khan, M. A. (2014). Students's Passion for Grades in Higher Education Institution in Pakistan. Procedia - Social and Behavioral Sciences, 112, 702-709. https://cyberleninka.org/article/n/1135048

Khan, M. J., Altaf, S., \& Kausar, H. (2013). Effect of Perceived Academic Stress on Students' Performance. FWU Journal of Social Sciences, 7(2), 146-151. http://sbbwu.edu.pk/journal/FWU\%20Journal\%20Vol.7,\%20No.2/6.\%20EFFECT\% 200F\%20PERCIEVED\%20ACADEMIC-1.pdf

Khawaja, N. G., Chan, S., \& Stein, G. (2017). The Relationship between Second Language Anxiety and International Nursing Students Stress. Journal of International Students, 7(3), 601-620. https://doi.org/10.5281/zenodo.570021

Kolko, D. J. (1980). Stress Management Techniques for Graduate Students: Cognitive Coping, Problem Solving and Time Management. Paper presented at the annual meeting of the Southeastern Psychological Association March 1980, (pp. ED: 192-230). Washington. https://eric.ed.gov/?id=ED192230

Lal, K. (2014). Academic Stress among Adolescent in Relation to Intelligence and Demographic Factors. American International Journal of Research in Humanities, Arts and Social Sciences, 5(1), 123-129. https://doi.org/10.12691/education-7-9-9

Lazarus, R., \& Folkman, S. (1984). Stress, Appraisal, and Coping. Springer.

Misra, R., \& McKean, M. (2000). College Students' Academic Stress and its Relation to their Anxiety, Time Management, and Leisure Satisfaction. American Journal of Health Studies, $16(1)$ 41-51. https://search.proquest.com/openview/c2c1309ac42c1cc4b74e146f6b0e260c/1?pqorigsite $=$ gscholar\&cbl $=30166$

Mosley, T. H., Jr, P. S., Neral, S. M., Dubbert, P. M., Grothues, C. A., \& Pinto, B. M. (1994). Stress, Coping, and Well-being among Third-year Medical Students. Academic medicine : journal of the Association of American Medical Colleges, 69(9), 765-767. https://doi.org/10.1097/00001888-199409000-00024

Mynbayeva, A., Sadvakassova, Z., \& Akshalova, B. (2017). Pedagogy of the Twenty-First Century: Innovative Teaching Methods, New Pedagogical Challenges in the 21st Century - Contributions of Research in Education. https://www.intechopen.com/predownload/58060

Nandamuri, P., \& Gowthami, C. (2011). Sources of Academic Stress: A study on Management Students. Journal of Management and Science, 1(2), 31-42. http://jms.nonolympictimes.org/Articles/4.pdf

Naseem, N., Naz, L., \& Zehra, N. (2019). Prevalence of Stress and Depression among University Students of Karachi. Pakistan Journal of Neurological Sciences (PJNS), 14(1), Article 10. https://ecommons.aku.edu/pjns/vol14/iss1/10/

Naveed, S., Qadir, T., Afzaal, T., \& Waqas, A. (2017). Suicide and its legal implications in Pakistan: A Literature Review. Cureus, 9(9), 1-6. https://doi.org/10.7759/cureus.1665

Pulido-Martos, M., Augusto-Landa, J., \& Lopez-Zafra, E. (2011). Sources of Stress in Nursing Students: A Systematic Review of Quantitative Studies. International Nursing Review, 59, 15-25. https://doi.org/10.1111/j.1466-7657.2011.00939.x 
Qamar, K., Khan, N. S., \& Kiani, B. M. (2015). Factors Associated with Stress among Medical Students. Journal of Pakistan Medical Association, 65(7), 753-755. https://pubmed.ncbi.nlm.nih.gov/26160086/

Radcliff, C., \& Lester, H. (2003). Undergraduate Medical Education. Perceived Stress during Undergraduate Medical Training: A Qualitative Study. Medical Education, 37(1), 3238. https://doi.org/10.1046/j.1365-2923.2003.01405.x

Rahman, B., Hamid, S., \& Gul, A. (2020). Impact of Stress on the Performance of University Students in the Light of Krashen's Affective Filter Theory. Liberal Arts and Social Sciences International Journal, 3(2), 59-64. https://doi.org/10.47264/idea.lassij/3.2.7

Reddy, K. J., Menon, K. R., \& Thattil, A. (2018). Academic Stress and its Sources Among University Students. Volume 11 (1): 531-537. Biomedical and Pharmacology Journal, 11(1), 531-537. https://dx.doi.org/10.13005/bpj/1404

Reed, D. A., Shanafelt, T. D., Satele, D. W., Power, D. V., Eacker, A., Harper, W., . . Dyrbye, L. N. (2011). Relationship of pass/fail grading and curriculum structure with wellbeing among preclinical medical students: a multi-institutional study. Academic Medicine, 86(11), 1367-73. https://doi.org/10.1097/ACM.0b013e3182305d81.

Rimm-Kaufman, S., \& Sandilos, L. (2011). Improving Students'Relationships with Teachers to Provide Essential Supports for Learning. Washington, DC: USA: American Psychological Association. https://www.apa.org/education/k12/relationships

Saeed, M. (2012). Pakhtun Men's Perceptions of the Conditions Promoting Domestic Violence in their Culture. PhD thesis, University of York.

Sarokhani, D., Delpisheh, A., Veisan, Y., Sarokhani, M., Manesh, R., \& Sayehmiri, K. (2013). Prevalence of Depression among University Students: A Systematic Review and Meta Analysis Study. Depression Research and Treatment, 373857. https://doi.org/10.1155/2013/373857

Shakil, M. (2019). A Qualitative Analysis of Suicides Committed by the Students in Pakistan. Pakistan Journal of Medical Research, 58(1), 35-40. https://search.proquest.com/openview/e3df9088a22c5207cbd71e2cb13d561e/1?pqorigsite $=$ gscholar \&cbl $=636375$

Shield, N. (2001). Stress, Active Coping and Academic Performance among Persisting and Non-persisting College Students. Journal of Applied Biobehavioural Research, 6(2), 65-81. https://doi.org/10.1111/j.1751-9861.2001.tb00107.x

Sidik, S. M., Rampal, L, \& Kaneson, N. (2003). Prevalence of emotional disorders among medical students in a Malaysian university. Asia Pacific Family Medicine, 2(4), 213217. https://doi.org/10.1111/j.1444-1683.2003.00089.x

Spence, N. D., Wells, S., Graham, K., \& George, J. (2016). Racial Discrimination, Cultural Resilience, and Stress. The Canadian Journal of Psychiatry, 61(5), 298-307. https://doi.org/10.1177/0706743716638653

Spring, L., Robillard, D., Gehlbach, L., \& Moore Simas, T. (2011). Impact of pass/fail grading on medical students' well-being and academic outcomes. Medical Education, 45, 867-77. https://doi.org/10.1111/j.1365-2923.2011.03989.x

Stallman, H. (2008). Prevalence of Psychological Distress in University Students: Implications for Service Delivery. Australian Family Physician, 87(8), 673-677. https://www.racgp.org.au/afpbackissues/2008/200808/200808stallman.pdf

Syed, A., Ali, S. S., \& Khan, M. (2018). Frequency of Depression, Anxiety and Stress Among the Undergraduate Physiotherapy Student. Pakistan Journal of Medical Sciences, 34(2), 468-471. https://doi.org/10.12669/pjms.342.12298 
Tan, J., \& Yates, S. (2011). Academic Expectations as Sources of Stress in Asian Students. Social and Psychological Education, 14, 389-407. https://doi.org/10.1007/s11218010-9146-7

Teh, C. K., Ngo, C. W., Zulkifli, R. A., \& Rammiya, V. (2015). Depression, Anxiety and Stress among Undergraduate Students: A Cross Sectional Study. Open Journal of Epidemiology, 5(4), 260-268. https://doi.org/10.4236/ojepi.2015.54030

Tresca, A. (2020, June 23). Understanding Stress Related to Time Management. https://stress.lovetoknow.com/Stress_Related_to_Time_Management

Uchil, H. (2017). The Effect of Stress on Students' Performance. Stress Management Professional International Journal, 5(1), 17-21.

Yousaf, S. U., Usman, B., \& Akran, M. (2016). Exploring the Causes of Stress and Coping with it Among Doctoral Level Students: Highlighting the importance of Information Collection and Management. Pakistan Journal of Information Management \& Libraries, $\quad 18(2), \quad 19-39$. http://journals.pu.edu.pk/journals/index.php/pjiml/article/viewFile/1095/580

Yusoff, M. S. (2011). The Validity and Reliability of Secondary School Stressor Questionnaire (3SQ) in Identifying Stressor among Adolescents in Secondary School. International Medical Journal, 18(2), 99-105.

Zenkour, A., \& Alghanmi, R. (2019). Stress Analysis of a Functionally Graded Plate Integrated with Piezoelectric Faces via a Four-unknown Shear Deformation Theory. Results in Physics, 12, 268-277. https://doi.org/10.1016/j.rinp.2018.11.045 


\section{Appendices}

Appendix 1: Semi-Structured Interview Guide

1. Name-

2. Department-----------------Year of Study

3. a) Boarder Student-----------b) Non-boarder Student-

4. Background education:

a. Studied at Government School system

b. Studied at Private School System

5. Parental economic status:

a. Poor (income less than RS:30000 per month-- $\$ 200 * 150$ (one dollar is roughly equal to 150

Pak rupee $)=\mathrm{RS}: 30000)$

b. Middle class (income ranges from RS:30000 to RS: 80000 per month)

c. Well-off (income more than RS:80000 per month)

6. Did you ever experience stress/pressure in your academic life at the University of Malakand?

a. Yes

b. No

7. Which of the following factor(s) in your opinion causes stress among students in the University of Malakand and how?

a. Lack of time management

b. Semester system and frequent exams

c. High study load and lengthy syllabi

d. Financial constraints

e. Favouritism and discrimination

f. Ineffective student-teacher relationship

g. Conventional teaching methodology

h. Family or parental expectations

i. Lack of adjustment of the university environment

8. What suggestions would you give to overcome academic stress among students?

Appendix 2: Participants' Profile

\begin{tabular}{|c|c|c|c|c|c|c|}
\hline $\begin{array}{l}\text { S. } \\
\text { No }\end{array}$ & $\begin{array}{l}\text { Name } \\
\text { name) }\end{array}$ & Department & $\begin{array}{l}\text { Year of } \\
\text { Study } \\
\text { (Semester) }\end{array}$ & $\begin{array}{l}\text { a. Boarder } \\
\text { b. Non- } \\
\text { boarder }\end{array}$ & $\begin{array}{l}\text { Parental } \\
\text { Income: } \\
\text { a., b., c., }\end{array}$ & $\begin{array}{l}\text { Did you ever } \\
\text { experience } \\
\text { academic stress? } \\
a=\text { Yes. } b=\text { No. }\end{array}$ \\
\hline 1 & Amin Rahman & Education & $1^{\text {st }}\left(1^{\mathrm{st}}\right)$ & $\mathrm{b}$ & $\mathrm{a}$ & $\mathrm{a}$ \\
\hline 2 & Kamil Raza & --do-- & $1^{\text {st }}\left(2^{\text {nd }}\right)$ & $\mathrm{a}$ & $\mathrm{a}$ & $\mathrm{a}$ \\
\hline 3 & Jamal Nasir & --do-- & $2^{\text {nd }}\left(3^{\text {rd }}\right)$ & $\mathrm{a}$ & $\mathrm{b}$ & $\mathrm{a}$ \\
\hline 4 & Sajjad Ali & --do-- & $2^{\text {nd }}\left(4^{\text {th }}\right)$ & $\mathrm{a}$ & a & a \\
\hline 5 & Aurang Zeb & --do-- & $3^{\text {rd }}\left(5^{\text {th }}\right)$ & $\mathrm{a}$ & $\mathrm{a}$ & $\mathrm{a}$ \\
\hline 6 & Ismail Jan & --do-- & $3^{\text {rd }}\left(6^{\text {th }}\right)$ & b & $\mathrm{c}$ & b \\
\hline 7 & Khan Alam & --do-- & $4^{\text {th }}\left(7^{\text {th }}\right)$ & $\mathrm{a}$ & $\mathrm{a}$ & $\mathrm{a}$ \\
\hline 8 & Muddasar Iqbal & --do-- & $4^{\text {th }}\left(8^{\text {th }}\right)$ & $\mathrm{a}$ & $\mathrm{a}$ & $\mathrm{a}$ \\
\hline 9 & Javed Ali & Sociology & $1^{\mathrm{st}}\left(1^{\mathrm{st}}\right)$ & $\mathrm{a}$ & $\mathrm{b}$ & $\mathrm{a}$ \\
\hline 10 & $\begin{array}{l}\text { Mohammad } \\
\text { Akbar }\end{array}$ & --do-- & $1^{\text {st }}\left(2^{\text {nd }}\right)$ & $\mathrm{a}$ & $\mathrm{a}$ & $\mathrm{a}$ \\
\hline 11 & Said Alam & --do-- & $2^{\text {nd }}\left(3^{\text {rd }}\right)$ & b & $\mathrm{a}$ & $\mathrm{a}$ \\
\hline 12 & Zeshan Khan & --do-- & $2^{\text {nd }}\left(4^{\text {th }}\right)$ & $\mathrm{a}$ & b & $\mathrm{a}$ \\
\hline 13 & $\begin{array}{l}\text { Moahmmad } \\
\text { Kaleem }\end{array}$ & --do-- & $3^{\text {rd }}\left(5^{\text {th }}\right)$ & $\mathrm{a}$ & $\mathrm{a}$ & $\mathrm{a}$ \\
\hline 14 & Waqar Ali & --do-- & $3^{\text {rd }}\left(6^{\text {th }}\right)$ & $\mathrm{a}$ & $\mathrm{a}$ & a \\
\hline 15 & Sami Khan & --do-- & $4^{\text {th }}\left(7^{\text {th }}\right)$ & $\mathrm{a}$ & $\mathrm{a}$ & $\mathrm{a}$ \\
\hline 16 & Murrad Khan & --do-- & $4^{\text {th }}\left(8^{\text {th }}\right)$ & b & b & $\mathrm{a}$ \\
\hline 17 & Anwar ul Haq & Biotechnology & $1^{\mathrm{st}}\left(1^{\mathrm{st}}\right)$ & $\mathrm{a}$ & $\mathrm{a}$ & $\mathrm{a}$ \\
\hline 18 & Ihsan Ali & --do-- & $1^{\text {st }}\left(2^{\text {nd }}\right)$ & $\mathrm{a}$ & $\mathrm{a}$ & $\mathrm{a}$ \\
\hline 19 & Husnain Khan & --do-- & $2^{\text {nd }}\left(3^{\text {rd }}\right)$ & $\mathrm{a}$ & $\mathrm{a}$ & $\mathrm{a}$ \\
\hline
\end{tabular}


A Qualitative Exploratory Study of the Factors Causing Academic Stress . . .

\begin{tabular}{|c|c|c|c|c|c|c|}
\hline 20 & $\begin{array}{l}\text { Jawad } \\
\text { Mohammad }\end{array}$ & --do-- & $2^{\text {nd }}\left(4^{\text {th }}\right)$ & $\mathrm{a}$ & $\mathrm{a}$ & $\mathrm{a}$ \\
\hline 21 & Ishtiaq Khan & --do-- & $3^{\text {rd }}\left(5^{\text {th }}\right)$ & $\mathrm{b}$ & $\mathrm{b}$ & $\mathrm{a}$ \\
\hline 22 & $\begin{array}{l}\text { Sohaib } \\
\text { Mohammad }\end{array}$ & --do-- & $3^{\text {rd }}\left(6^{\text {th }}\right)$ & $\mathrm{a}$ & $\mathrm{a}$ & $\mathrm{a}$ \\
\hline 23 & Adnan Khan & --do-- & $4^{\text {th }}\left(7^{\text {th }}\right)$ & $\mathrm{a}$ & $\mathrm{a}$ & $\mathrm{a}$ \\
\hline 24 & Saddiq Jan & --do-- & $4^{\text {th }}\left(8^{\text {th }}\right)$ & $\mathrm{a}$ & $\mathrm{a}$ & $\mathrm{a}$ \\
\hline 25 & Mohammad Jan & $\begin{array}{l}\text { Management } \\
\text { Studies }\end{array}$ & $1^{\mathrm{st}}\left(1^{\mathrm{st}}\right)$ & $\mathrm{b}$ & $\mathrm{a}$ & $\mathrm{a}$ \\
\hline 26 & Khaista Rahman & --do-- & $1^{\text {st }}\left(2^{\text {nd }}\right)$ & $\mathrm{a}$ & $\mathrm{a}$ & $\mathrm{a}$ \\
\hline 27 & $\begin{array}{l}\text { Mohammad } \\
\text { Dawood }\end{array}$ & --do-- & $2^{\text {nd }}\left(3^{\text {rd }}\right)$ & $\mathrm{a}$ & $\mathrm{c}$ & $\mathrm{a}$ \\
\hline 28 & Sami Ullah & --do-- & $2^{\text {nd }}\left(4^{\text {th }}\right)$ & $\mathrm{b}$ & b & $\mathrm{a}$ \\
\hline 29 & Gulab Sher Khan & --do-- & $3^{\text {rd }}\left(5^{\text {th }}\right)$ & $\mathrm{a}$ & a & $\mathrm{a}$ \\
\hline 30 & Furqan Khan & --do-- & $3^{\text {rd }}\left(6^{\text {th }}\right)$ & $\mathrm{a}$ & $\mathrm{a}$ & $\mathrm{a}$ \\
\hline 31 & Ihsan ul haq & --do-- & $4^{\text {th }}\left(7^{\text {th }}\right)$ & $\mathrm{a}$ & $\mathrm{a}$ & $\mathrm{b}$ \\
\hline 32 & Shafiq ur Rahman & --do-- & $4^{\text {th }}\left(8^{\text {th }}\right)$ & $\mathrm{a}$ & b & $\mathrm{a}$ \\
\hline 33 & Atta Ullah & Economics & $1^{\text {st }}\left(1^{\text {st }}\right)$ & $\mathrm{b}$ & $\mathrm{a}$ & $\mathrm{a}$ \\
\hline 34 & Inayat Rahman & --do-- & $1^{\text {st }}\left(2^{\text {nd }}\right)$ & $\mathrm{a}$ & $\mathrm{a}$ & $\mathrm{a}$ \\
\hline 35 & Faiz Mohammad & --do-- & $2^{\text {nd }}\left(3^{\text {rd }}\right)$ & $\mathrm{a}$ & $\mathrm{b}$ & $\mathrm{a}$ \\
\hline 36 & Bahadar Khan & --do-- & $2^{\text {nd }}\left(4^{\text {th }}\right)$ & $\mathrm{b}$ & a & $\mathrm{a}$ \\
\hline 37 & Said Jan & --do-- & $3^{\text {rd }}\left(5^{\text {th }}\right)$ & $\mathrm{a}$ & $\mathrm{a}$ & $\mathrm{a}$ \\
\hline 38 & Shokat Alam & --do-- & $3^{\text {rd }}\left(6^{\text {th }}\right)$ & $\mathrm{a}$ & a & $\mathrm{a}$ \\
\hline 39 & $\begin{array}{l}\text { Mohammad } \\
\text { Zaman }\end{array}$ & --do-- & $4^{\text {th }}\left(7^{\text {th }}\right)$ & $\mathrm{b}$ & $\mathrm{b}$ & $\mathrm{a}$ \\
\hline 40 & Ziauddin Khan & --do-- & $4^{\text {th }}\left(8^{\text {th }}\right)$ & $\mathrm{a}$ & $\mathrm{a}$ & $\mathrm{a}$ \\
\hline 41 & Mir Alam & $\begin{array}{l}\text { Computer } \\
\text { Science }\end{array}$ & $1^{\mathrm{st}}\left(1^{\mathrm{st}}\right)$ & a & $\mathrm{a}$ & $\mathrm{a}$ \\
\hline 42 & Nisar Khan & --do-- & $1^{\text {st }}\left(2^{\text {nd }}\right)$ & a & b & $\mathrm{a}$ \\
\hline 43 & Khan Alam & --do-- & $2^{\text {nd }}\left(3^{\text {rd }}\right)$ & $\mathrm{a}$ & a & $\mathrm{a}$ \\
\hline 44 & Bachi Rahim & --do-- & $2^{\text {nd }}\left(4^{\text {th }}\right)$ & $\mathrm{b}$ & $\mathrm{b}$ & $\mathrm{a}$ \\
\hline 45 & $\begin{array}{l}\text { Javed } \\
\text { Mohammad }\end{array}$ & --do-- & $3^{\text {rd }}\left(5^{\text {th }}\right)$ & $\mathrm{a}$ & $\mathrm{a}$ & $\mathrm{a}$ \\
\hline 46 & Bakhtiar Khan & --do-- & $3^{\text {rd }}\left(6^{\text {th }}\right)$ & $\mathrm{a}$ & $\mathrm{c}$ & b \\
\hline 47 & $\begin{array}{l}\text { Sheer } \\
\text { Mohammad }\end{array}$ & --do-- & $4^{\text {th }}\left(7^{\text {th }}\right)$ & $\mathrm{a}$ & $\mathrm{a}$ & $\mathrm{a}$ \\
\hline 48 & Said Lal Jan & --do-- & $4^{\text {th }}\left(8^{\text {th }}\right)$ & b & b & $\mathrm{a}$ \\
\hline 49 & Fakhruddin & English & $1^{\text {st }}\left(1^{\text {st }}\right)$ & $\mathrm{a}$ & $\mathrm{a}$ & $\mathrm{a}$ \\
\hline 50 & $\begin{array}{l}\text { Shabir } \\
\text { Mohammad }\end{array}$ & --do-- & $1^{\text {st }}\left(2^{\text {nd }}\right)$ & $\mathrm{a}$ & $\mathrm{a}$ & $\mathrm{a}$ \\
\hline 51 & Junaid Khan & --do-- & $2^{\text {nd }}\left(3^{\text {rd }}\right)$ & $\mathrm{a}$ & b & $\mathrm{a}$ \\
\hline 52 & Niaz Mohammad & --do-- & $2^{\text {nd }}\left(4^{\text {th }}\right)$ & $\mathrm{b}$ & $\mathrm{a}$ & $\mathrm{a}$ \\
\hline 53 & Sheeda Arif & --do-- & $3^{\text {rd }}\left(5^{\text {th }}\right)$ & a & $\mathrm{a}$ & $\mathrm{a}$ \\
\hline 54 & Kamal Khan & --do-- & $3^{\text {rd }}\left(6^{\text {th }}\right)$ & $\mathrm{a}$ & $\mathrm{a}$ & $\mathrm{a}$ \\
\hline 55 & Sajid Anwar & --do-- & $4^{\text {th }}\left(7^{\text {th }}\right)$ & $\mathrm{a}$ & a & $\mathrm{a}$ \\
\hline 56 & Imran khan & --do-- & $4^{\text {th }}\left(8^{\text {th }}\right)$ & $\mathrm{b}$ & $b$ & $\mathrm{a}$ \\
\hline 57 & Said Rauf Khan & Chemistry & $1^{\text {st }}\left(1^{\text {st }}\right)$ & a & a & $\mathrm{a}$ \\
\hline 58 & $\begin{array}{l}\text { Mohammad } \\
\text { Osman }\end{array}$ & --do-- & $1^{\text {st }}\left(2^{\text {nd }}\right)$ & $\mathrm{a}$ & $\mathrm{a}$ & $\mathrm{a}$ \\
\hline 59 & Tahir Jan & --do-- & $2^{\text {nd }}\left(3^{\text {rd }}\right)$ & $\mathrm{a}$ & b & $\mathrm{a}$ \\
\hline 60 & Sareer Ahmed & --do-- & $2^{\text {nd }}\left(4^{\text {th }}\right)$ & b & a & $\mathrm{a}$ \\
\hline 61 & Mati Ur Rahman & --do-- & $3^{\text {rd }}\left(5^{\text {th }}\right)$ & $\mathrm{a}$ & $\mathrm{a}$ & $\mathrm{a}$ \\
\hline 62 & Mobarak Jan & --do-- & $3^{\text {rd }}\left(6^{\text {th }}\right)$ & a & $\mathrm{a}$ & $\mathrm{a}$ \\
\hline 63 & Hasheem Khan & --do-- & $4^{\text {th }}\left(7^{\text {th }}\right)$ & a & $\mathrm{c}$ & a \\
\hline 64 & Amir Sohail & --do-- & $4^{\text {th }}\left(8^{\text {th }}\right)$ & $\mathrm{b}$ & $\mathrm{a}$ & $\mathrm{a}$ \\
\hline
\end{tabular}




\begin{tabular}{|c|c|c|c|c|c|c|}
\hline 65 & $\begin{array}{l}\text { Mohammad } \\
\text { Zahid }\end{array}$ & Mathematics & $1^{\text {st }}\left(1^{\text {st }}\right)$ & $\mathrm{a}$ & $\mathrm{b}$ & $\mathrm{a}$ \\
\hline 66 & Farooq Jan & --do-- & $1^{\text {st }}\left(2^{\text {nd }}\right)$ & $\mathrm{a}$ & $\mathrm{a}$ & $\mathrm{a}$ \\
\hline 67 & Asghar Ali & --do-- & $2^{\text {nd }}\left(3^{\text {rd }}\right)$ & $\mathrm{a}$ & $\mathrm{a}$ & $\mathrm{a}$ \\
\hline 68 & Musawar Shah & --do-- & $2^{\text {nd }}\left(4^{\text {th }}\right)$ & $\mathrm{b}$ & $\mathrm{a}$ & $\mathrm{a}$ \\
\hline 69 & Alam Khan & --do-- & $3^{\text {rd }}\left(5^{\text {th }}\right)$ & $\mathrm{a}$ & b & $\mathrm{a}$ \\
\hline 70 & Said Nawab & --do-- & $3^{\text {rd }}\left(6^{\text {th }}\right)$ & $\mathrm{a}$ & $\mathrm{a}$ & $\mathrm{a}$ \\
\hline 71 & Sargand Khan & --do-- & $4^{\text {th }}\left(7^{\text {th }}\right)$ & $\mathrm{b}$ & $\mathrm{c}$ & $\mathrm{a}$ \\
\hline 72 & Shomial Khan & --do-- & $4^{\text {th }}\left(8^{\text {th }}\right)$ & $\mathrm{a}$ & $\mathrm{a}$ & $\mathrm{a}$ \\
\hline 73 & Omar Farooq & Pharmacy & $1^{\text {st }}\left(1^{\mathrm{st}}\right)$ & $\mathrm{a}$ & $\mathrm{a}$ & $\mathrm{a}$ \\
\hline 74 & Rashid Khan & --do-- & $1^{\text {st }}\left(2^{\text {nd }}\right)$ & b & $\mathrm{a}$ & $\mathrm{a}$ \\
\hline 75 & $\begin{array}{l}\text { Mohammad } \\
\text { Zahoor }\end{array}$ & --do-- & $2^{\text {nd }}\left(3^{\text {rd }}\right)$ & $\mathrm{a}$ & $\mathrm{a}$ & $\mathrm{a}$ \\
\hline 76 & Nasir Khan & --do-- & $2^{\text {nd }}\left(4^{\text {th }}\right)$ & $\mathrm{a}$ & $\mathrm{c}$ & $\mathrm{a}$ \\
\hline 77 & $\begin{array}{l}\text { Sheeda } \\
\text { Mohammad }\end{array}$ & --do-- & $3^{\text {rd }}\left(5^{\text {th }}\right)$ & $\mathrm{a}$ & $\mathrm{a}$ & $\mathrm{a}$ \\
\hline 78 & Sher Akbar & --do-- & $3^{\text {rd }}\left(6^{\text {th }}\right)$ & b & a & $\mathrm{a}$ \\
\hline 79 & Gohar Ali & --do-- & $4^{\text {th }}\left(7^{\text {th }}\right)$ & $\mathrm{a}$ & b & $\mathrm{a}$ \\
\hline 80 & Saeed Khan & --do-- & $4^{\text {th }}\left(8^{\text {th }}\right)$ & $\mathrm{a}$ & $\mathrm{a}$ & $\mathrm{a}$ \\
\hline \multicolumn{4}{|c|}{ Total } & $\begin{array}{l}a=20(25 \%) \\
b=60(75 \%)\end{array}$ & $\begin{array}{l}a=60(75 \%) \\
b=17(21.25 \%) \\
c=3(3.75 \%)\end{array}$ & $\begin{array}{l}a=77(96.25 \%) \\
b=3(3.75 \% 0\end{array}$ \\
\hline
\end{tabular}

\section{Note:}

${ }^{1}$ Different names such as Pukhtuns or Pakhtuns, Pahstuns, and Pathans have been used for around 40 million semi-nomadic people inhabiting southern and eastern Afghanistan and in Pakistan, mainly in the KhyberPakhtunkhwa province, Federally Administrative Tribal Areas (FATA), Karachi city, and western Baluchistan (Nawaz 2011 cited in Saeed, 2012). Similarly different terms such as Pashto, Pakhto and Pushto have been used for their language. 